\title{
ANÁLISE DA PERSONALIDADE DO AGENTE COMO CIRCUNSTÂNCIA JUDICIAL DE INDIVIDUALIZAÇÃO DA PENA NO DIREITO PENAL CONTEMPORÂNEO
}

\author{
Fernanda da Rosa Cristino* \\ Joelíria Vey de Castro**
}

\begin{abstract}
RESUMO: Este trabalho analisa a aplicabilidade da circunstância judicial personalidade do agente como componente da individualização penal e sua compatibilidade com o Direito Penal Contemporâneo, através da exposição de seus conceitos basilares e posterior confronto com sua prática. De forma breve, é apresentada a construção dos juízos aceitos e descartados pela sistemática penal, visando provir o estudo de argumentações esclarecedoras da contradição existente. A dosimetria da pena e aspectos da individualização desta são abordados, enfatizando a personalidade, objeto da análise, por meio de conceituações feitas pelas áreas psicológica e jurídica. Finalizando o estudo, há a exposição de decisões favoráveis e desfavoráveis relativas à matéria, como meio exemplificativo e motivacional de futuras decisões.
\end{abstract}

PALAVRAS - CHAVE: Personalidade. Individualização. Pena.

ABSTRACT: This paper work analyses the applicability of the judicial circumstance know as agent personality as component of penal individualization and its compatibility with comntemporaneous Penal Law, throught the exposition of its basilar concepts and posterior confront with its practice. The building of accepted and discarded judgment by the penal systematization is briefly presented, as well as the principles related to penalty, aiming to result the study of clarifying argumentation of the existent contradiction. The penal dosimetry and aspects of its individualization are referred, emphasizing the personality, analysis object, through evaluation done by psychological and juridicial areas. Finalizing the study, there is the exposition of favorable and unfavorable decision regarding this subject as an exemplifying and motivative means of future decisions.

KEY-WORDS: Personality. Individualization. Penal.

*Autora. Especialista em Ciências Criminais (UNAMA/IDRS), pós-graduanda em Direitos Humanos e Segurança Pública (Renaesp/FADISMA), graduada em Odontologia e Direito (UFSM).

**Orientadora. Mestre em Integração Latino Americana (UFSM), professora do Curso de Direito (UFSM). 


\section{CONSIDERAÇÕES INICIAIS}

A motivação do estudo desta face da pena decorre do anseio em efetivar garantias há muito tempo dispostas à sociedade, contudo, apenas atualmente percebidas ou perquiridas. Perante a ciência da igualdade, da faculdade do julgamento individualizado, da interpretação do Direito Penal como ultima ratio, sobrevivem decisões fundamentadas no Direito Penal do Autor, bem como a ineficiência dessas sentenças remete o imaginário coletivo a defender o retrocesso à instituição de penas desumanas, como meio de assegurar a sua proteção.

Nesse contexto, a análise da personalidade do agente como parte da composição da pena, aspecto esse extremamente subjetivo até aos profissionais competentes (psicólogos, psiquiatras, médicos, etc.), estando destinada ao arbítrio de um jurista (ainda que togado), afasta-o de suas limitações legais. Dessa forma, contribui não para a análise do fato, mas para a manifestação de seus tumultos interiores, constituindo, portanto, um dos fatores determinantes do retrocesso ao temido Direito Penal Máximo.

Como propõe José Antonio Paganella Boschi, a personalidade supera as singelas avaliações que pessoas fazem uma das outras. Trata-se de algo dinâmico, que nasce com o indivíduo e se modifica com ele. Mesmo que fosse possível um diagnóstico conclusivo sobre o assunto, não seria legítima a consideração da personalidade do acusado como fator de exacerbação da sanção, pois representaria uma punição ao seu modo de ser, concebendo a intervenção estatal com o fim de alterar a personalidade do criminoso uma de suas finalidades. ${ }^{1}$

Sob essa perspectiva, vislumbra-se a relevância do estudo proposto, o qual alheio à obtenção de soluções precisas ou ao esgotamento do tema, visa somar às pesquisas existentes, alertando a necessidade de discernimento das funções do Direito Penal, do juiz e da pena, a fim de evitar a disposição de conquistas seculares.

\section{FUNDAMENTOS PARA A APLICAÇÃO DA PENA}

A legitimidade e a credibilidade do sistema penal de um Estado social democrático de direito estão condicionadas a sua capacidade protetiva de reduzir a violência que assola a sociedade, conjuntamente à finalidade de assegurar garantias formais e materiais sem extrapolar os limites impostos por esse tipo de estado. O Direito Penal é somente um de muitos instrumentos disponíveis ao Estado para lutar contra a criminalidade. São, portanto, o caráter subsidiário e a natureza fragmentária, que

\footnotetext{
${ }^{1}$ BOSCHI, José Antonio Paganella. Das penas e seus critérios de aplicação. 3 e. Porto Alegre: Livraria do Advogado, 2004 , p. 207.
} 
definem o princípio da intervenção mínima, os conformadores do modelo de Direito Penal gerado segundo posturas minimalistas. ${ }^{2}$

A fragmentariedade faz com que tutela penal se restrinja aos bens jurídicos imprescindíveis à coexistência pacífica dos homens e a ações cuja ofensa gerada obstrua o satisfatório viver em sociedade. Dessa forma, não está legitimada a atuar sobre a tutela moral, funções estatais, ideologia, questões religiosas, nem em fatos de escasso relevo. A subsidiariedade só admite o ramo repressivo do Direito quando seus outros ramos não são suficientes para solucionar o problema. Esse caráter atua externamente através de alternativas não formais ou de ramos diversos ao penal e internamente segundo orientações de uma intervenção penal, todavia, amena. ${ }^{3}$

Cezar Roberto Bitencourt enfatiza essa concepção, uma vez que a ultima ratio ou princípio da intervenção mínima preconiza a limitação do poder incriminador do Estado, promovendo a criminalização de condutas apenas quando constituirem meio necessário para a tutela de determinado bem jurídico. Destarte, assevera que o Direito Penal deverá manifestar-se somente em situações onde os demais ramos do Direito forem considerados inadequados ou inaptos a tutelar bens relevantes à vida do indivíduo e da sociedade. Para ele, as justificativas desse entendimento advêm de a sanção penal constituir um risco à existência social do afetado e com isso, produzir também um dano social. $^{4}$

Nessa esteira, também Júlio Fabrini Mirabete apregoa que a intervenção do Direito Penal somente é legítima diante de exigências de uma proteção mais intensa à coletividade, quando o delito consiste em um injusto mais grave, bem como desvela uma culpabilidade reprovável, demonstrando a real necessidade da sanção penal. Por isso, a pena se destina a situações em que represente o único meio de proteção eficiente e suficiente da ordem social frente a ataques relevantes. ${ }^{5}$

A menor intervenção penal, portanto, é a representação da atuação sensata do Estado destinado a tutelar penalmente os bens relevantes da sociedade, não descartando a criminalização compatível com a filosofia de veemente necessidade e da ineficácia de outros meios da política criminal.

O Código Penal Pátrio experimentou sucessivas alterações, como a incidência da medida de segurança somente nos casos de inimputabilidade e a transferência de suas

\footnotetext{
${ }^{2}$ INSTITUTO DE EDUCAÇÃo LUIZ FLÁVIO GOMES. Pós - Graduação em Ciências Criminais. Política Criminal. São Paulo. [200-]. Não paginado, impresso. Ibid., p. 7-9.

${ }^{4}$ BITENCOURT, Cezar Roberto. Manual de direito penal: parte geral. 6. ed. São Paulo: Editora Saraiva, 2000. p. 41 . v. 1.

${ }^{5}$ MIRABETE, Julio Fabrini. Manual de direito penal. 9.ed. São Paulo: Editora Atlas S.A.,1995, p. 241. v. 1.
} 
funções de prevenção e assistência para o domínio das penas, seus artigos 59 do $\mathrm{CP}$ e $1^{\circ}$ da Lei de Execuções agora subentendem as finalidades retributiva, preventiva e de ressocialização da sanção. Todavia, em seu conjunto, a legislação penal prioriza a maximização do Estado Penal. ${ }^{6}$

A pena para crimes mais graves distante de seu objetivo de ressocializar para a liberdade, socializa o indivíduo para viver na prisão. A punição justa existe apenas teoricamente, a prevenção geral trata de uma ambição remota, uma vez que a autodeterminação é essência do ser humano. Analisado esse contexto, segundo Renato Marcão, a prática expressa a finalidade retributiva da pena. ${ }^{7}$

\section{DA APLICAÇÃO DA PENA}

A garantia constitucional da individualização da pena ou método trifásico, consagrada no artigo $5^{\circ}$, inciso XLVI da Carta Magna, ocorre em três fases distintas: individualização judicial, legislativa e executória. Na primeira, são selecionados os fatos puníveis e estabelecidos critérios de fixação da pena, através da avaliação das circunstâncias judiciais, constantes no artigo 59, do Código Penal, resultando o quantum da pena-base. Na segunda, há a concretização da cominação abstrata da fase anterior, por meio da análise de circunstâncias legais, genéricas, taxativas e obrigatórias, denominadas agravantes quando correspondentes ao rol previsto nos artigos 61 e 62 do Código Penal e atenuantes, prenunciadas nos artigos 65 e 66 do mesmo Código, conformando-se assim, a pena provisória. A última fase, por sua vez, ocorre no momento de cumprimento da sanção criminal, onde é constatada a presença ou ausência de causas especiais de aumento ou diminuição de pena, majorantes e minorantes, determinando-se assim, a pena definitiva. ${ }^{8}$

A individualização penal, nas palavras de Luiz Vicente Cernicchiaro, quando a interpretação não se resumir a mero exercício burocrático, constitui grande roteiro para a aplicação material da sanção, afastando a simples análise aritmética, não esgotando a extensão do instituto. ${ }^{9}$

Da análise do art. 59 do CP, portanto, depreendem-se quatro conseqüências necessárias: a determinação das penas aplicáveis e a ocorrência de cominação

\footnotetext{
${ }^{6}$ BOSCHI, José Antônio Paganella. op. cit., p. 131-132.

${ }^{7}$ MARCÃO, Renato; MARCON, Bruno. Direito penal brasileiro. Do idealismo normativo à realidade prática. Jus Navigandi, Teresina, a. 6, n. 55, mar. 2002. Disponível em: http://jus2.uol.com.br/doutrina/texto.asp?id=2780. Acesso em: 15 abr. 2006.

${ }^{8}$ COLLE, Juliana de Andrade. Critérios para a valoração das circunstâncias judiciais (art. 59, do CP) na dosimetria da pena. Jus Navigandi, Teresina, a. 9, n. 572, 30 jan. 2005. Disponível em: <http://jus2.uol.com.br/doutrina/texto.asp?id=6232>. Acesso em: 17 set. 2005 , p. 1.

9 CERNICCHIARO, Luiz Vicente. Aplicação da pena. Site do Curso de Direito da UFSM. Santa Maria-RS. Disponível em: < http://www.ufsm.br/direito/artigos/penal/aplicacao.htm >. Acesso em: 01 out. 2005.
} 
alternativa; dentro dos limites estabelecidos, a quantidade de pena correspondente ao agente; o regime de cumprimento da pena privativa de liberdade e a possibilidade de substituição desta por outra. ${ }^{10}$

O cerne da análise proposta, a circunstância judicial personalidade do agente, situa-se na primeira etapa da individualização penal, onde os limites abstratamente fixados na lei penal geram, com sua demasiada amplitude, o risco da arbitrariedade.

\subsection{Compreendendo a Personalidade e suas Relações}

Sempre houve controvérsias a respeito da concepção da personalidade. Entre as inúmeras tendências destacam-se as naturezas biológica e existencial suprabiológica. Consoante a primeira, a genética também determinaria a interação do indivíduo com o mundo, seu temperamento, afetividade, etc. A outra compreende o indivíduo como o resultado de interações bio-psico-sociais. ${ }^{11}$

Portanto, a personalidade poderia ser considerada da seguinte forma:

Personalidade é a organização dinâmica dos traços no interior do eu, formados a partir de genes particulares que herdamos das existências singulares que suportamos e das percepções individuais que temos do mundo, capazes de tornar cada indivíduo único em sua maneira de ser e desempenhar seu papel social. ${ }^{12}$

Os seres humanos, com isso, não podem ser considerados resultado exclusivo do meio, tampouco um aglomerado de genes. Também entre si não podem ser sintetizados, uma vez que apesar da igualdade ontológica (essência) possuem funcionalidades diversas. ${ }^{13}$

Para Eunofre Marques, a personalidade se refere ao modo de ser e interagir do indivíduo. Caracteriza sua forma de apreender, interpretar e reagir diante de experiências e, posteriormente, incorporá-las de modo a construir seu interior. De acordo com sua interpretação, ela deverá ser a mesma desde o nascimento até a morte (atemporal), a fim de servir como referencial para a abordagem adequada do indivíduo. 14

\footnotetext{
${ }^{10}$ ZAFFARONI, Eugenio Raúl; PIERANGELI, José Henrique. Manual de direito penal brasileiro: parte geral. 4. ed. São Paulo: Editora Revista dos Tribunais, 2002, p. 829 .

${ }^{11}$ BALLONE, G.J. Personalidade, in. Psiqweb, internet, revisto em 2003. Disponível em: <http://www.psiqweb.med.br/ persona/personal.html> Acesso em: 05 ago.

${ }^{12}$ Ibid.

${ }^{13}$ BALLONE, G.J. op. cit.

${ }^{14}$ Ibid.
} 
Henry A. Murray, no entanto, entende a personalidade não como uma estrutura fixa e sim como "um múltiplo contínuo de processos estruturados". ${ }^{15} \mathrm{O}$ mesmo entendimento é expresso por José Antonio Paganella Boschi, para qual ela nasce com o indivíduo e se modifica com ele, abrangendo variações de intensidade, genética, traços emocionais e comportamentais. ${ }^{16}$

A pretensão de classificar a personalidade sob aspectos positivos e negativos remete o estudo à compreensão de outros termos a ela relacionados, entre eles a normalidade. Para muitos, constitui função de um ideal coletivo obtido a partir de julgamentos de valor em relação aos outros ou o padrão de comportamentos e entendimentos, prejudicando, dessa forma, as opiniões minoritárias. ${ }^{17}$

Marcelo Sales França enfatiza o fato de essa conceituação ser relativa por envolver fatores sociais, culturais e estatísticos. Devido à sutileza de seus limites, também menciona a facilidade com que ela pode adentrar no campo da anormalidade. ${ }^{18}$

Ruy Rosado Aguiar Júnior menciona ainda as definições de temperamento, caráter e traço de personalidade. O temperamento seria a interferência de aspectos hereditários e fisiológicos sobre o ritmo, afetividade e vitalidade do indivíduo. O caráter, designação de aspectos morais e para os traços, o senso comum costuma elaborar uma extensa lista de adjetivos correspondentes como: honesto, amigável, artístico, calmo, irritante, tolerável, oportunista, radical, pessimista, etc., sendo a combinação desses a constituição da personalidade. ${ }^{19}$

Entretanto, ante a tentativa de unificar conceituações, Salo de Carvalho salienta a infinidade de significados atribuídos pelos psicólogos a esses termos, havendo um deles extraído aproximadamente cinqüenta definições apenas para a personalidade. Destarte, dependem da referência teórica adotada. ${ }^{20}$

Portanto, o emprego de noções equivocadas dos termos analisados representa incontestável perigo nas mãos daqueles que detêm o poder. ${ }^{21}$

\subsection{A Personalidade como Circunstância Judicial}

A concepção doutrinária atual a cerca da pertinência da personalidade no rol de circunstâncias judiciais a serem analisadas pelo magistrado leciona o afastamento desse

\footnotetext{
${ }^{15}$ KLUCKHOHN, Clyde; MURRAY, Henry A. Personalidade: na natureza, na sociedade, na cultura.Tradução: Neil R. da Silva. 2. ed. Belo Horizonte: Editora Itatiaia Limitada, 1969. v. 1. p. 32. (Biblioteca de Estudos Sociais e Pedagógicos - $1^{a}$ série - Ciências Sociais).

${ }^{16}$ BOSCHI, José Antonio Paganella. op. cit., p. 208.

${ }^{17}$ BERGERET, Jean. A personalidade normal e patológica. 3. ed. Porto Alegre: Artmed, 1998, p.23.

${ }^{18}$ FRANÇA, Marcelo Sales. Personalidades psicopáticas e delinqüentes: semelhanças e dessemelhanças. Jus Navigandi, Teresina, ano 9 , n. 734,9 jul. 2005. Disponível em: 〈http://jus2.uol.com.br/doutrina/texto.asp?id=6969>. Acesso em 11 ago. 2006, p. 10.

${ }^{19}$ AGUIAR JÚNIOR, Ruy Rosado. Aplicação da pena. 4. ed. Porto Alegre: AJURIS, Escola Superior da Magistratura, 2003 , p. 41

${ }^{20}$ CARVALHO, Amilton Bueno de; CARVALHO, Salo de. Aplicação da pena e garantismo. 3. ed. Rio de Janeiro: Editora Lúmen Júris, 2004, p. 55.

${ }^{21}$ BERGERET, Jean. op. cit., p. 23.
} 
mérito. A argumentação para tal posicionamento se constitui em críticas referentes ao aspecto estrutural e organizacional do Poder Judiciário, bem como a fundamentação ideológica do Direito Penal Contemporâneo. ${ }^{22}$

Os escassos recursos material e humano das instituições públicas impossibilitam que o julgador usufrua de assistência profissional para a realização dessa avaliação. Além disso, a carência de contato entre este e o criminoso impede a construção de qualquer parecer referente a aspectos pessoais do imputado. ${ }^{23}$

Sucintamente, Juliana de Andrade Colle enumera quatro motivos para o afastamento dessa análise da competência judicial:

Primeiro, porque ele não tem um preparo técnico em caráter institucional. As noções sobre psicologia e psiquiatria adquire como autodidata. Segundo, porque não dispõe de tempo para se dedicar a tão profundo estudo...Terceiro, porque não vige no processo penal a identidade física, muitas vezes a sentença é dada sem ter o juiz qualquer contato com o réu. Quarto, porque em razão das deficiências materiais do Poder Judiciário e da polícia, o processo nunca vem suficientemente instruído de modo a permitir uma rigorosa análise da personalidade. ${ }^{24}$

De fato, a partir da leitura de sentenças e acórdãos, percebe-se a grande incidência de afirmações genéricas ou restritas a determinações de temperamento e caráter. Não há a investigação das bases estruturais da personalidade. ${ }^{25} \mathrm{O}$ ideal, para evitar a incidência dessas decisões, seria que o juiz não hesitasse em declarar a impossibilidade de valorar a circunstância, reconhecendo a carência de elementos ou sua inaptidão profissional. ${ }^{26}$

Nessa esteira, Salo de Carvalho, ao dissertar sobre o princípio da secularização e seus efeitos na esfera jurídico-penal, declara a impossibilidade do Estado criminalizar ou penalizar a esfera do pensamento, devendo limitar-se ao tratamento das condutas danosas, sob pena de desvio. Tal conduta acarretaria um retrocesso ao estado de natureza, onde cada indivíduo era juiz em causa própria. ${ }^{27}$

A permissão da demanda judicial sobre a esfera íntima do condenado, usufruindo da pena como instrumento de modificação deste, consistiria na prática de um Estado Totalitário, adverso às teorias do atual Estado Democrático de Direito. ${ }^{28}$

\footnotetext{
${ }^{22}$ MENEZES, Bruno Seligman de. Fixação da pena-base à luz do garantismo penal. Campinas: Editora Minelli, 2005 , p. 78.

${ }^{23}$ Ibid., p. 78-79.

${ }^{24}$ COLLE, Juliana de Andrade. Critérios para a valoração das circunstâncias judiciais (art. 59, do CP) na dosimetria da pena. Jus Navigandi, Teresina,

a. 9, n. 572, 30 jan. 2005. Disponível em: <http://jus2.uol.com.br/doutrina/texto.asp?id=6232>. Acesso em: 17 set. 2005 , p. 1.

${ }_{25}^{25}$ BOSCHI, José Antonio Paganella. op. cit., p. 209.

${ }^{26}$ COLLE, Juliana de Andrade. op. cit., p. 8.

${ }^{27}$ CARVALHO, Amilton Bueno de; CARVALHO, Salo de. op. cit., p. 7.

${ }^{28}$ BOSCHI, José Antonio Paganella. op. cit., p. 213.
} 
Nas palavras de Bruno Seligman de Menezes, "hoje se busca punir o agente pelo que cometeu e não mais pelo que pensa ou que é, sob pena de retornarmos ao medievo, quando pessoas eram queimadas porque divergiam em pensamento de quem detinha o poder". 29

Somando-se a isso, o Sistema Processual Penal Acusatório vigente exige a comprovação fática de todas as hipóteses e argumentos levados a juízo, sob pena inviabilizar a refutação do argüido pelas partes e gerar a nulidade por falta de fundamentação, como o critério analisado não possui verificabilidade processual, explícita é a sua inconstitucionalidade. ${ }^{30}$

De acordo com o princípio constitucional da fundamentação das decisões (artigo 93, inciso IX da Constituição Federal), o magistrado deve explicitar os critérios utilizados, no caso da personalidade, a base conceitual e metodológica que propiciou a formação da decisão. Sendo o campo de saber exigido para essa análise da competência da psiquiatria, psicologia e psicanálise, não há como o julgador estabelecer tal juízo. ${ }^{31}$

Entretanto, algumas opiniões, as quais confundem o significado do termo personalidade com traços, caráter e temperamento, persistem na concepção da personalidade como critério fundamental da individualização da pena, como responsável pela especificidade desta a cada indivíduo analisado. ${ }^{32}$

Enrico Ferri defende, por imposição da vida e da ciência, que a justiça penal deve regular o crime como relação de infração da norma penal e como expressão da personalidade do criminoso. A solução encontrada pelo autor refere à necessidade do recrutamento de juízes penais especializados em definir a personalidade criminal em casos menos relevantes e da organização pericial de antropólogos criminalistas para os casos mais complexos. ${ }^{33}$

Michel Foucault entende essa delegação de poder como a instauração de pequenas justiças e juízes paralelos, pessoas que não são os juízes da infração, mas que possuem o poder de decidir se o agente está apto ou não a usufruir da tutela penal, prolongando a instância judiciária além da sentença. ${ }^{34}$

\footnotetext{
${ }^{29}$ MENEZES, Bruno Seligman de. op. cit., p. 81.

${ }^{30}$ CARVALHO, Amilton Bueno de; CARVALHO, Salo de. op. cit., p. 54.

${ }^{31}$ Ibid., p. 56.

${ }^{32}$ TRACHTA, Dário do Amaral. Por qual razão é necessário, para ver-se cumprir o restante da pena? Universo Jurídico. Disponível em: <http://www.uj.com.br/default_impressão.asp>. Acesso em: 03 ago. 2006.

${ }^{33}$ FERRI, Enrico. Princípios de direito criminal. 2. ed. Campinas: Editora Bookseller, 1999, p. 331

${ }^{34}$ FOUCAULT, Michel. Vigiar e punir. 30. ed. Petrópolis: Editora Vozes, 2005, p. 22.
} 
Além disso, há que se verificar o papel dos peritos psiquiatras, se as perguntas que deverão responder são em termos de responsabilidade ou de administração da pena. Neste último caso, seu papel seria de "conselheiro de punição". ${ }^{35}$

Ilustrando a questão, o psiquiatra forense Antônio José Eça ao ser questionado a respeito do caso de Suzane, que participou de um complô para assassinar seus pais, menciona não ser a pena o meio adequado para tratar anomalias da personalidade:

O senhor a considera normal? R. A idéia de matar ficou amadurecendo na cabeça dela... Ela tem alguma coisa ruim dentro dela, uma perversidade, uma anormalidade de personalidade. Qual a punição mais adequada para Suzane? R. Se você perguntar ao povo, vão dizer que ela tem que morrer na cadeia e os promotores vão querer promover a vingança contra ela. Não é a solução. Suzane não pode ser tratada com igualdade se ela é desigual. Essa menina não tem de sofrer pena, mas ir para um hospital de custódia e tratamento, como a Casa de Custódia de Taubaté. Ela ficará lá até melhorar. Quanto tempo leva essa melhora? R. Para sempre. Personalidade não muda, a maldade está arraigada na alma dela, não tem cura. Suzane ficará lá para o resto da vida... ${ }^{36}$

Nesta senda, José Antonio Paganella Boschi revela o paradoxo existente quando se compara a redução prevista em benefício dos acusados que apresentam perturbação da saúde mental (redução da pena de 1 a 2/3) com aqueles portadores de transtornos da personalidade. Estes arcam com uma valoração maior de censura, em virtude da classificação negativa de sua personalidade na primeira fase da individualização penal. Todavia, ambos os transtornos afetam igualmente a capacidade de agir do indivíduo. ${ }^{37}$

A personalidade como circunstância judicial de aplicação da pena não se adequa à secularização moderna do Direito penal e à separação deste da moral. Isso porque, já fora comprovado pela evolução histórica que a subjetivação do Direito Penal é fator de arbitrariedade e desigualdade. ${ }^{38}$

Luigi Ferrajoli ensina que os fins e limites do Direito Penal são conseqüências da interação de três princípios: o primeiro determina a sua missão exclusiva de impedir condutas lesivas concretas a bem jurídicos alheios; o segundo, exige que o juízo verse apenas sobre fatos proibidos penalmente, passíveis de comprovação e refutação e o terceiro, que a sanção não deve interferir em matéria moral. ${ }^{39}$

A partir dessas premissas, o modelo político-criminal atual é composto:

Um modelo político-criminal de intervenção mínima que respeite, de forma absoluta e universal, o "ser" do "outro", pois se o cidadão tem o dever de

\footnotetext{
${ }^{35}$ Ibid., p. 22.

${ }^{36}$ BALLONE, G.J. op. cit

${ }^{37}$ BOSCHI, José Antonio Paganella. op. cit., p. 213

${ }^{38}$ CARVALHO, Amilton Bueno de; CARVALHO, Salo de. op. cit., p. 61.

${ }^{39}$ FERRAJOLI, Luigi. Direito e razão: teoria do garantismo penal. São Paulo: Editora Revista dos Tribunais, 2002. p. 207-208.
} 
cumprir a lei, ao mesmo tempo tem o direito de ser interiormente perverso e continuar sendo sem a ingerência dos aparatos de controle social. ${ }^{40}$

Explícito é o paradoxo, o retrocesso e, em conseqüência, a arbitrariedade estabelecida quando há a percepção da personalidade como critério judicial para a aplicação da pena.

\subsection{Tendências Jurisprudenciais}

A persistência de opiniões adversas defendidas por doutrinadores consagrados, como Júlio Fabrini Mirabete que concebe a personalidade como o conjunto de qualidades morais, boa ou má índole ${ }^{41}$, o ensinamento de Cezar Roberto Bitencourt, que acrescenta a análise da sensibilidade ético-social e de infrações criminais cometidas pelo réu durante a menor idade ${ }^{42}$, faz com que as decisões jurisprudências demonstrem demasiado paradoxo.

Visando a ilustração da questão, expõe-se a opinião do Des. Manuel José Martinez Lucas:

(...) sempre entendi que todos os inquéritos policiais e processos judiciais a que responde ou respondeu o réu devem ser sopesados, na avaliação de seus antecedentes, posição que, para gáudio meu, acabou prevalecendo nesta Câmara Criminal. Nesse sentido, não se pode negar, de modo algum, que o apelante tinha, já por ocasião do fato que é objeto do presente processo, maus antecedentes. Em conseqüência, pode-se afirmar também que tinha ele conduta social desajustada e personalidade, senão voltada à prática do crime, no mínimo desrespeitosa às normas e aos princípios que regem a boa convivência social. ${ }^{43}$

Nesta senda, a decisão do Des. Roque Miguel Fank, fundamentando a personalidade negativa à incidência de antecedentes:

Contudo, em que pese não haja condenação anterior, de modo a configurar a reincidência, conforme se infere dos documentos fls. 78/79, o fato é que o réu é agente contumaz do delito de furto, dentre outros, já sofrendo pelo menos uma outra condenação, além da qual versam estes autos. Atento à personalidade do agente, entendo que não pode a pena ficar no mínimo, como pretende o apelante, restando correto o aumento operado quando da dosimetria da pena na sentença hostilizada. ${ }^{44}$

\footnotetext{
${ }^{40}$ CARVALHO, Amilton Bueno de; CARVALHO, Salo de. op. cit., p. 13.

${ }^{41}$ MIRABETE, Júlio Fabrini. op. cit., p. 291.

${ }^{42}$ BITENCOURT, Cezar Roberto. op. cit., p. 517

${ }^{43}$ BRASIL. Tribunal de Justiça do Rio Grande do Sul. Apelação Criminal no 70013195417. Primeira Câmara Criminal. Apelante: Edison Messias R.

B. Filho. Apelado: Ministério Público. Relator: Des. Manuel José Martinez Lucas. Porto Alegre, 28 de junho de 2006. Lex: jurisprudência do Tribunal

de Justiça do RS. Disponível em: 〈http://www.tj.rs.gov.br>. Acesso em: 14 ago. 2006.

${ }_{44}$ BRASIL. Tribunal de Justiça do Rio Grande do Sul. Apelação Criminal no 70014108146. Oitava Câmara Criminal. Apelante/ Apelado: Marco Aurélio da Rosa Chagas e Ministério Público. Relator: Des. Roque Miguel Fank. Porto Alegre, 21 de junho de 2006. Lex: jurisprudência do Tribunal de Justiça do RS. Disponível em: 〈http://www.tj.rs.gov.br>. Acesso em: 14 ago. 2006.
} 
Essa análise superficial é usada inclusive como presunção de repetição de condutas lesivas, como expresso no voto do Des. Sylvio Baptista Neto, culminando no caso exemplificado, em manutenção da prisão provisória:

...embora o delito não tenha tanta gravidade, o paciente, a princípio, demonstra que sim. Já esteve envolvido em crimes de ameaça e lesão corporal dolosa, mostrando, por presunção, evidentemente, que tem uma personalidade agressiva... A garantia da ordem pública tem como escopo a prevenção de reprodução de fatos criminosos. Ou porque é propenso às práticas delituosas ou porque, em liberdade, encontrará os mesmos estímulos relacionados com a infração cometida... ${ }^{45}$

Também o Des. Marco Aurélio de Oliveira Canosa compartilha de opinião

oposta à defendida neste estudo:

Além disso, relativamente à "maneira de ser dos agentes", tenho que são portadores de personalidade marca de nota anti-social, revelada inclusive pelo móvel do crime. Com efeito, da pena brilhante do mestre Hungria (Comentários ao Código Penal, volume V, Forense, 1981) apreende-se que "os motivos determinantes constituem, no direito penal moderno, a pedra de toque do crime. Não há crime gratuito ou sem motivo e é no motivo que reside a significação mesma do crime. O motivo é o adjetivo do elemento moral do crime. É através do porquê do crime, principalmente, que se pode rastrear a personalidade do criminoso, e identificar a sua maior ou menor anti-sociabilidade". ${ }^{46}$

Entretanto, emergem decisões que evitam estabelecer juízos a cerca do que não

se refere à matéria jurídica, como dispõe o Des. Aymoré Roque Pottes de Mello:

...o simples fato de possuir processos em andamento não é suficiente para negativar tal operadora. Ainda no ponto, registro não há prova técnica que autorize juízo conclusivo (positivo ou negativo) sobre a operativa da personalidade do réu. Neste sentido, transcrevo a seguinte nota doutrinária: “(...) a personalidade, todavia, é mais complexa do que essas simples manifestações de caráter ou de temperamento, não sendo fácil determinar-lhe o conteúdo porque o trabalho exige conhecimento técnico-científico de antropologia, psicologia, medicina e psiquiatria e, de outro lado, aquele que se dispõe realizálo tendo a racionar com base nos próprios atributos de personalidade, que elege, não raro como paradigma. Urge revisarmos, portanto, a idéia de que os problemas relacionados à personalidade são fontes de maior periculosidade, como delineada pelo legislador na redação original do nosso Código, nesse ponto coerente, aliás, com as disposições que ensejavam imposição cumulativa de pena e de medida de segurança". Neste diapasão... ${ }^{47}$

\footnotetext{
${ }^{45}$ BRASIL. Tribunal de Justiça do Rio Grande do Sul. Hábeas Corpus n ${ }^{\circ}$ 70015142953. Sétima Câmara Criminal. Impetrante/Paciente: Rogério Ulrich Fich. Autoridade Coatora: Juiz de Direito. Relator: Des. Sylvio Baptista Neto. Porto Alegre, 01 de junho de 2006. Lex: jurisprudência do Tribunal de Justiça do RS. Disponível em: 〈http://www.tj.rs.gov.br>. Acesso em: 14 ago. 2006.

${ }^{46}$ BRASIL. Tribunal de Justiça do Rio Grande do Sul. Apelação Criminal no 70011447638. Segunda Câmara Criminal. Apelante/ Apelado: Cláudio R dos Santos e Ministério Público. Apelante: Ângela Valéria S. Oliveira. Relator: Des. Marco Aurélio de Oliveira Canosa. Porto Alegre, 25 de maio de 2006. Lex: jurisprudência do Tribunal de Justiça do RS. Disponível em: 〈http://www.tj.rs.gov.br>

Acesso em: 14 ago. 2006

${ }^{47}$ BRASIL. Tribunal de Justiça do Rio Grande do Sul. Apelação Criminal no 70014876551. Sexta Câmara Criminal. Apelante/Apelado: Ministério Público e Sandro Lopes Oliveira. Relator: Des. Aymoré Roque Pottes de Mello. Porto Alegre, 08 de junho de 2006. Lex: jurisprudência do Tribunal de Justiça do RS. Disponível em: <http://www.tj.rs.gov.br>. Acesso em: 14 ago. 2006.
} 
E quanto às decisões que emanam o mesmo teor da expressa pelo Des. Aymoré Roque Pottes de Mello, espera-se que haja a perpetuação de tal fundamentação, haja vista sua constitucionalidade, justiça e conformidade ao Estado Democrático de Direito vigente, conquista secular, cuja arbitrariedade coloca em risco sua manutenção.

\section{CONSIDERAÇÕES FINAIS}

Ante a exposição de inúmeros argumentos, a análise da personalidade do agente como circunstância judicial de aplicação da pena denota ser algo temerável.

Permitir o julgamento da esfera íntima do indivíduo, mesmo que em prol da ordem pública, gera o retrocesso aos regimes totalitários e suas mazelas, eis que a história nos revela que essa evolução culmina em anormalidade maior, demência ou insanidade, tal qual a proposta pelos ideais fascistas e nazistas. O suplício não representa sofrimento maior que o tolhimento da alma, a carência de expressão, o pensar uniforme. Se realmente esses ideais fossem eficientes, revoluções não teriam ocorrido, visando derroca-los.

A esfera jurídica já é demasiado ampla e controvertida para os doutos, quem dirá se a eles cobrarem o saber médico e psicológico. Além disso, ao se questionar o bem jurídico a ser tutelado em cada conduta criminosa, verificar-se-á que a personalidade não prepondera nos índices de fatores delituosos, e sim aspectos econômicos e políticos. Não se furta exclusivamente pelo prazer de subtrair, tampouco se trafica apenas para entorpecer a mente.

Sentenciar a ocorrência de transtornos da personalidade corresponde à instauração de medidas adversas à sanção, haja vista a fundamentação proporcional e igualitária da pena: necessidade e conformidade para com a reprovação e prevenção do crime; tratamento igual aos iguais e desigual aos desiguais.

Por isso, propõe-se o afastamento desse critério da esfera jurídica ou então a sua omissão justificada na expressão dos juízos, a fim de manter as conquistas seculares, reconhecendo o esforço dos antepassados, evitando a arbitrariedade velada que assola e compromete os benefícios do Estado Democrático de Direito.

\section{REFERÊNCIAS}

AGUIAR JÚNIOR, Ruy Rosado. Aplicação da pena. 4. ed. Porto Alegre: AJURIS, Escola Superior da Magistratura, 2003.

BALLONE, G.J. Personalidade, in. Psiqweb, internet, revisto em 2003. Disponível em: <http://www.psiqweb.med.br/ persona/personal.html>. Acesso em: 05 ago. 
BERGERET, Jean. A personalidade normal e patológica. 3. ed. Porto Alegre: Artmed, 1998.

BITENCOURT, Cezar Roberto. Manual de direito penal: parte geral. 6. ed. São Paulo: Editora Saraiva, 2000. v.1.

BOSCHI, José Antonio Paganella. Das penas e seus critérios de aplicação. 3. ed. Porto Alegre: Livraria do Advogado, 2004.

CARVAlHO, Amilton Bueno de; CARVAlHO, Salo de. Aplicação da pena e garantismo. 3.ed. Rio de Janeiro: Editora Lumen Juris, 2004.

CERNICCHIARO, Luiz Vicente. Aplicação da pena. Site do Curso de Direito da

UFSM. Santa Maria-RS. Disponível em:

http://www.ufsm.br/direito/artigos/penal/aplicacao.htm >. Acesso em: 01 out. 2005.

COLLE, Juliana de Andrade. Critérios para a valoração das circunstâncias judiciais (art. 59, do CP) na dosimetria da pena. Jus Navigandi, Teresina, a. 9, n. 572, 30 jan. 2005. Disponível em: <http://jus2.uol.com.br/doutrina/texto.asp?id=6232>. Acesso em: 17 set. 2005.

FERRAJOLI, Luigi. Direito e razão: Teoria do Garantismo Penal. São Paulo: Editora Revista dos Tribunais, 2002.

FERRI, Enrico. Princípios de direito criminal. 2. ed. Campinas: Editora Bookseller, 1999.

FOUCAULT, Michel. Vigiar e punir. 30. ed. Petrópolis: Editora Vozes, 2005.

FRANÇA, Marcelo Sales. Personalidades psicopáticas e delinqüentes: semelhanças e dessemelhanças. Jus Navigandi, Teresina, ano 9, n. 734, 9 jul. 2005. Disponível em: <http://jus2.uol.com.br/doutrina/texto.asp?id=6969>. Acesso em 11 ago. 2006.

INSTITUTO DE EDUCAÇÃO LUIZ FLÁVIO GOMES. Pós - Graduação em Ciências Criminais. Política Criminal. São Paulo. [200-]. Não paginado, impresso.

KLUCKHOHN, Clyde; MURRAY, Henry A. Personalidade: na natureza, na sociedade, na cultura. Tradução: Neil R. da Silva. 2. ed. Belo Horizonte: Editora Itatiaia Limitada, 1969. v. 1. (Biblioteca de Estudos Sociais e Pedagógicos $-1^{\text {a }}$ série - Ciências Sociais).

MARCÃO, Renato; MARCON, Bruno. Direito Penal brasileiro. Do idealismo normativo à realidade prática. Jus Navigandi, Teresina, a. 6, n. 55, mar. 2002. Disponível em: <http://jus2.uol.com.br/doutrina/texto.asp?id=2780>. Acesso em: 15 abr. 2006.

MENEZES, Bruno Seligman de. Fixação da pena-base à luz do garantismo penal. Campinas: Editora Minelli, 2005.

MIRABETE, Julio Fabrini. Manual de direito penal. 9. ed. São Paulo: Editora Atlas S.A.,1995. v.1.

TRACHTA, Dário do Amaral. Por qual razão é necessário, para ver-se cumprir o restante da pena? Universo Jurídico. Disponível em: <http://www.uj.com.br/default_impressão.asp>. Acesso em: 03 ago. 2006.

ZAFFARONI, Eugenio Raúl; PIERANGELI, José Henrique. Manual de direito penal brasileiro: parte geral. 4. ed. São Paulo: Editora Revista dos Tribunais, 2002. 